\title{
Debating Restorative Justice
}

Chris Cunneen

Carolyn Hoyle 


\section{Debating Restorative Justice}

Chris Cunneen

and

Carolyn Hoyle

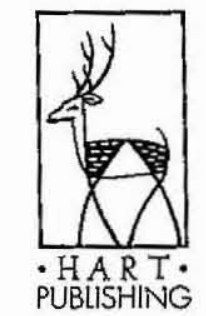

OXFORD-PORTLAND OREGON

2010 

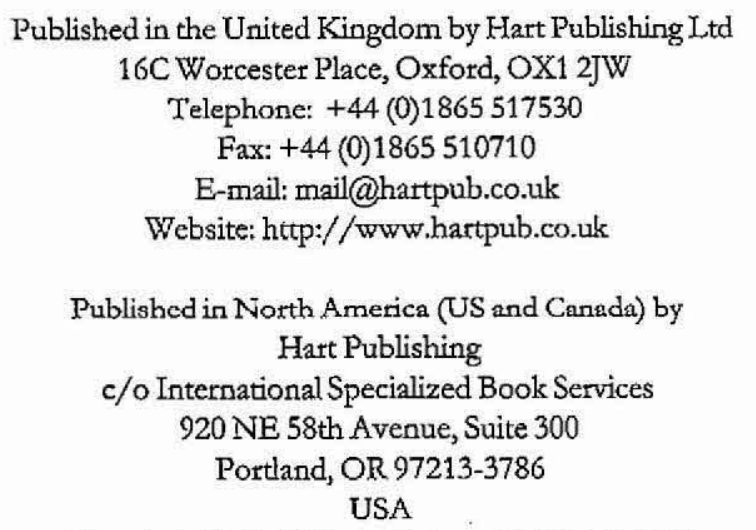

Tel: +15032873093 or toll-free: (1) 8009446190

Fax: +15032808832

E-mail: ordcrs@isbs.com

Website: http://www.isbs.com

(C) Chris Cunneen and Carolyn Hoyle 2010

Chris Cunneen and Carolyn Hoyle have asserted their right under the Copyright, Designs and Patents Act 1988, to be identified as the authors of this work.

\footnotetext{
All rights reserved. No part of this publication may be reproduced, stored in a retrieval system, or transmitted, in any form or by any means, without the prior permission of Hart Publishing, or as expressly permitted by law or under the terms agreed with the appropriate reprographic rights organisation.

Enquiries concerning reproduction which may not be covered by the above should be addressed to Hart Publishing Ltd at the address above.

British Library Cataloguing in Publication Data

Data Available
}

ISBN: 978-1-84946-022-4

Typeset by Hope Services, Abingdon

Printed and bound in Great Britain by

TJ International Ltd, Padstow, Cornwall 


\section{Series Editors Preface}

This innovative and exciting series was inspired by one of the best-known philosophy books of the latter half of the twentieth century. Utilitarianism for and against by JJC Smart and Bernard Williams, published in 1973, is described on its cover as ' $[t]$ wo essays... written from opposite points of view'. It is one of the classics of the modern literature on utilitarianism.

Based on this model, books in the Debating Law series will cuntain two essays of around 30,000 words, each developing a strong and intellectually rigorous argument on a topic of contemporary and ongoing debate. The aim is to stimulate, challenge and inform by bringing contrasting perspectives together in the one volume.

The Debating Law series offers a forum for scholarly argument and advocacy. It gives essayists the opportunity to make a fresh and provocidive statement of a normative position freed from a tight requirement of 'balance'. Although debaters are encouraged to exchange ideas during the writing process, it is not the intention that the two essays will answer one anuther but rather that each will provide an independent statement of a point of view. Authors may take different tacks and address different issues within the broad topic, and the starting points or foundations of the case on une side may be different from those of the case on the other side. The confident expectation is that the debate format will sharpen issues, and highlight areas of both agreement and disagreement, in an effective and illuminating way.

The Debating Law series is designed for a wide readership. The aim is that each essay should be self-contained, accessibly written and only lightly endnoted. Books in the series will be valuable for those coming to the topic for the first time and also for the experienced reader seeking a stimulating, thought-provoking and concise statement of different points of view. 'They will provide valuable resources for teaching as well as lively discussions of important issues of wide current interest.

\section{Peter Cane}




\section{Acknowledgements by Carolyn Hoyle}

Some of the arguments in my essay draw on previous articles I have written alone or with collcagucs. I am grateful to them and to the vibrant intellectual life of the Oxford Centre for Criminology for providing encouragement and inspiration. Over the last decade my thinking about restorative justice has benefited from conversations with my Oxford colleagues, Lucia Zedner and Andrew Ashworth, as well as with undergraduate and postgraduate students, in particular those in my Restorative Justice course in the MSc in Criminology and Criminal Justice. I am grateful to my current and former students-particularly Brctt IIartley, Mark Walters and Stephan Noguera - for research assistance and, more importantly, for pointing out contradictions in my arguments.

I am indebted to Richard Young with whom I carried out years of research into restorative justice and co-authored many essays. In particular, the discussion on punishment draws on a chapter which we wrote together but which built on his reflections on the penal philosophies in evidence in restorative encounters.

I am gratcful to Pctcr Canc and to my husband, David Rose, both of whom commented on - and certainly improved - an earlier draft. And, finally, I dedicate the essay to my wonderful children, Jacob and Daniel Rose. As energetic boys of 10 and 6 they test my restorative principles to the limit. At the end of this long essay, I confess that Jacob, in particular, knows that sometimes I fail to put my restorative principles into practice, and denigrate rather than reintegrate! 


\section{Acknowledgements by Chris Cunneen}

Discussions about restorative justice always seem to arouse passionate responses and over the last twenty years or su I have had the pleasure of engaging in and learning from many formal and informal debates with a wide variety of people. I want to particularly acknowledge the work of Harry Blagg, Kathy Daly and Julie Stubbs whose insights and scholarship have influenced the development of my own ideas. I have also spoken, in various contexts, with many people who were offenders or victims of crime-their views have also been important in clarifying my own ideas. Of course neither my colleagues nor the unwilling participants in the criminal justice system should be held accountable for the arguments expressed in this book.

My contribution to this book would not have been possible without the excellent work of my research associate Ms Fiona Allison. Peter Cane provided helpful comments on the draft text. As always, my partner Kate was supportive well beyond what any reasonable person might expect. 


\section{Contents}

Series Editors Preface $\quad \mathrm{v}$

Acknowledgements by Carolyn Hoyle vii

Acknowledgements by Cbris Cunneen ix

The Case for Restorative Justice by Carolyn Hoyle $\quad 1$

I. Introduction 1

II. A Route through Definitional constraints and

A. Introduction 6

B. Defining Victims and Offenders 8

C. Crimes and Harms 11

D. Restorative Justice and Restorative Practices 14

III. Community at the Heart of Restorative Justice 16

IV. A reflection on the Imbalance between Restorative Aspirations and Restorative Practices 26

A. Restorative Justice in the UK: All Talk and Little or No Action 26

B. A Criminology of Hope 30

C. Appeals to Communitarianism 34

V. Restorative Justice and Criminal Justice: Complementary not Contradictory 40

A. A Challenge to an Unhelpful Dichotomy 40

B. The Case for the Coexistence of Restorative and Criminal Justice

C. A Framework for the Coexistence of Restorative and Criminal Justice

1. Engaging community in search of appropriate participants

2. A qualified defence of coercion 
xii Contents

3. The aims of punishment and the boundaries of proportionality

4. Who should facilitate restorative processes? 69

5. Conclusion 71

VI. In Defence of Restoration in the 'Deep end' of Criminal Justice

A. Domestic Violence 75

B. Crimes against Humanity 81

C. Everything has its Limits 89

VII. Conclusion: Restoration for Fragmented Communities 91

Bibliography 95

The Limitations of Restorative Justice by Chris Cunncen 101

I. Introduction 101

II. Why Restorative Justice 109

A. Concept of Origins 109

B. Explaining the Rise of Restorative Justice 118

C. Policy Transfer and the Globalisation of Restorative Justice 125

III. Creating Ideal Victims and Offenders 132

A. The Victim 134

B. Victim Trauma 138

C. Does Restorative Justice Offer a Better Deal for Victims? 141

D. The Offender 146

E. Structural Inequalities and the Offender/Victim Relationship 150

1. Violence against women $\quad 150$

2. Hate crime 155

3. Social inequality 156

F. Victims, Offenders, Rights and Incommensurability 157 
Contents xiii

IV. Law, State and Community 161

A. The Role of Law and the State 162

B. Policing and Ctiminalisation 167

C. Punishment and Risk 169

D. The Community 174

E. Transitional Justice 177

V. Conclusion: Searching for Truth in Restorative Justice 183

Index 189 


\section{The Case for Restorative Justice}

\section{INTRODUCTION}

$\mathrm{E}$

ARLY WRITINGS on restorative justice were firmly rooted in critiques of mainstream criminal justice. Restorativists were at great pains to emphasise shortcomings and then, having painted a grim picture of the criminal justice landscape, would present the reader with the alternative of restorative justice- the white rabbit pulled triumphantly from the hat. Whilst section II. below explores the contested nature of definitions of restorative justice, it might he helpful before we go any further to provide a brief description of restorative justice for the uninitiated reader.

Although a universal definition of restorative justice remains elusive, probably the most frequently quoted definition is provided by Tony Marshall, who sees it as

a process whereby all the parties with a stake in a particular offence come together to resolve collectively how to deal with the aftermath of the offence and its implication for the future. ${ }^{1}$

An alternative (though not too dissimilar) definition is provided by Paul McCold and Ted Wachtel, who describe restorative justice

\footnotetext{
1 'T Marshall 'The Evolution of Restorative Justice in Britain' (1996) 4 (4) European Joumal on Criminal Policy Research, 21, 37. Notwithstanding that it is often guoted, Marshall's definition has been widely criticised (eg, over its failure to specify the aims and outcomes of the process; who the stakeholders should be; and the nature of stakeholder participation): see, eg, J Dignan, Understanding Victims and Restorative Justice (Maidenhead, Open University Press, 2005) 2-5.
} 


\section{The Case for Restorative Justice}

as a process where those primarily affected by an incident of wrongdoing come together to share their feelings, describe how they were affected and develop a plan to repair the harm done or prevent reoccurrence. $^{2}$

They add that the essence of restorative justice is a collaborative problem-solving approach to social discipline intended to reintegrate individuals and repair affected communities'. ${ }^{3}$

What is clear from these definitions is the inclusive and collaborative nature of restorative justice's problem-solving focus, and that for an intervention to be considered to be restorative the parties have to come together in dialogue as they do in restorative conferencing and direct mediation. Further, that the testorative justice process reaches beyond victims and offenders by encompassing other stakeholders, including the wider community affected by crimes. Hence, restorative justice can be contrasted with criminal justice, even though restorative justice practices are typically situ-. ated within criminal justice systems.

Criminal justice refers to the statutory responses to crime and disorder of organisations such as the police, prosecutors, defence lawyers, the courts, the prisons, and probation and management offender agencies. It draws on a set of normative and theoretical justifications for attempting to limit and control the actions of citizens and, in those cases where citizens transgress, for sanctioning their behaviout and causing them pain. Such justifications fall into backward- and forward-looking aims. Forward-looking philosophies include deterrence (trying to persuade people not to reoffend), incapacitation (physically preventing them from reoffending) and rehabilitation (using education or therapy to change people's attitudes and behaviour to stop them reoffending). However, when restorative justice is compared to criminal justice, most commentators have in mind the backward-looking justifica-

$2 \mathrm{P}$ McCold and T Wachtel, 'Restorative justice theory validation' in E Weitekamp and H-J Kerner (eds), Restorative Justice: Theoretical Foundations (Devon, Willan Publishing, 2002) 113.

${ }^{3}$ Ibid. 
tion of retribution. Retributive justice responds to the offence committed, tather than trying to prevent further offending. It treats all citizens as moral actors who ate responsible for their behaviour. Hence, it aims to punish transgressions rather than heal the transgressor, although only with as much punishment as fits the crime. In other words, the punishment must be proportionate to the crime. Retributive justice focuses on the offender and pays little regard to victims or to the wider community. Clearly, restorative justice is a distinct sentencing practice (more like mediation than other sentences such as prison or probation) and is driven by a philosophy distinct from other justifications for punishment, particularly retribution.

Restorative justice, its early advocates argued, provides a new lens through which to see crime and identify the appropriate and just responses to it. These early treatises were aspirational, even evangelistic, but tather unsophisticated. ${ }^{4}$ In promoting the benefits of testorative justice they found it necessary to reject outright criminal justice and, in order to justify this tejection, to present it as little more than victim-insensitive, state-sponsored vengeance. Failing to acknowledge the various victim-centred and reparative measures that were already being introduced into the criminal justice system, they presented restorative and retributive justice in dichotomous terms, with the former representing all that was good about community responses to crime and the latter all that was harmful with the state monopoly over justice. Restorative justice was promoted as the answer to society's criminal ills, with its promise to bring together victims, offenders and their communities, whilst keeping the state at atm's length.

Whilst praising inclusive restorative approaches, the early literature, with few exceptions, failed to problematise concepts such as 'victim', 'offender' or 'community'. Victims and offenders were

${ }^{4}$ For a critique of evangelism in the early restorative justice literature, see J Pratt, Beyond Evangelical Criminology: The Meaning and Significance of Restorative Justice' in I Aertsen, TDaems and L Roberts (eds), Institutionalizing Restorative Justice (Cullompton, Willan, 2006). 


\section{The Case for Restorative Justice}

presented as homogeneous groups, 'communities' were presumed to be supportive and inclusive, or at the very least benign, with 'society' seen as largely irtelevant. Criminal justice was criticised for having too much regard for society and too little for victims or communities, as if the latter gtoups were not part of wider society. All in all, concepts were blutred or undefined and the new lens had a distinctly rosy hue. This is not to say that the new product did not deserve promotion, rather that it was worthy of, and could stand up to, depiction and analysis that had integrity.

This essay makes the case for restorative justice. It argues that restorative justice can and should have a role to play in responding to most crimes and incivilities in most jurisdictions. But it does so without reliance on false dichotomies and without erecting straw men. It is unhelpful in seeking to understand the potential of restorative justice to start with the question of what is wrong with criminal justice, as so many academic commentators have. Rather, we should start with the question of what harms befall society when some of its members commit offences or behave in uncivil ways towards one other. We should not be constrained by official categories of 'victims', 'offenders' and 'crimes', but should consider barms done to citizens by criminality or antisocial behaviour. And we should then explore the various ways in which society can respond to repair those harms and to restore order, and what role restorative approaches can have in that response.

Thinking about harms in this way reveals the potential of both restorative and criminal justice, and the scope for complementary approaches that draw on both. This, of course, requires careful consideration of the potential and the limitations of both restorative and criminal justice but rejects the presumption that we should choose between the two. This essay presents arguments both for the exclusive use of restorative justice for many non-serious offences and for approaches that integrate restorative and retributive philosophies and thereby provide the scope for taking restorative practices into the 'deep end' of criminal justice (see section VI. for an explanation of the 'deep end' and 'shallow end' of criminal justice). Indeed, it is explicitly critical of the current reluctance to 
use restorative processes in anything but the 'shallow end' of criminal justice, most notably for young offenders or for minor offences. Hence, it considers the potential, and dangers, of restorative practices in the broader societal response to two 'deep end' crimes that test the efficacy of criminal justice: domestic violence and crimes against humanity.

In presenting the case for restorative justice, this essay adopts a clear normative stance that communities and the state in late modern society should be mote restorative in responding to the harms caused by crimes, antisocial behaviours and other incivilities. It does not make a plea for a return to some romanticised notion of traditional community justice. And its pro-restorative position is not premised on the belief that the state has no appropriate role in tesponding to conflicts in different communities, no mattcr how divided or alienated those communities might be. Furthermore, it is cognisant of the dangers posed by more participatory and dialogic approaches to crimes.

What follows primatily draws on theories and philosophies of justice, rather than on empirical research. This is not because empirical research on restorative justice is without value but because it is ultimately inadequate to the task of establishing a normative position. Furthermore, some of the research on restorative justice is built on a false premise-that it is meaningful to compare restorative conferences with courts in order to evaluate the relative efficacy of both. Such comparative work is not useless-indeed, it provides valuable information on the differences and similarities between both processes, and it measures programme integrity and the extent to which restorative goals are realised in practice-however, it cannot provide proof that restorative justice is superior to criminal justice, or vice versa. This is because in asking questions about the participation of victims and offenders in the process, and the response of offenders to the process, it compares the proverbial apples with oranges. At least some of the questions which lead to the apparently greater satisfaction of both victims and offenders with restorative processes are heavily biased in its favour: questions such as 'Did you teceive an apology?', 'Did you 


\section{The Case for Restorative Justice}

feel that the apology was sincere?', Did the offender understand the harm caused to you?', 'Did people indicate that you were forgiven?' are much more likely to be answered in the affirmative by those who experience restorative justice than by those who go to court. This is simply because these are the primary goals of restorative justice, but not of the court process. Whilst rarely drawing on the evidence about restorative justice in practice, this essay acknowledges up front that restorative justice often fails to live up to its potential; that there is, as in all areas of criminal justice, oftentimes a gap between justice in books and justice in action. Programme integrity is sometimes compromised, and organisational resources and sometimes apathy can conspire against the appropriate use of restorative principles in the real world. Nonetheless, given that the administration of justice can be attended to, there is value in considering the potential of restorative justice theory.

\section{A ROUTE THROUGH DEFINITION.AL CONSTRAINTS AND IMPRECISION}

\section{A. Introduction}

This section challenges some of the definitions used in the literature on restorative and criminal justice which limit our imagination and understanding of the two forms of justice and the relationship between them, as well as their potential to tackle harms caused by crime and disorder.

In the absence of a universally agreed definition of 'restorative justice', the concept has become deeply contested amongst its proponents and critics. Most restorative theoretical frameworks, including my own, encompass values, aims and processes that have as their common factor attempts to repair the harm caused by criminal or other types of antisocial behaviour. Restoration should address emotional as well as material loss, safety, damaged relationships, and the dignity and self-respect of victims and othes stakeholders recognised as having a legitimate interest in determin. 